\title{
The Effect Of NAFTA On Trade And Investment Between Member Countries
}

\author{
Beverly J. Frickel, University of Nebraska at Kearney, USA
}

Vani V. Kotcherlakota, University of Nebraska at Kearney, USA

Frank A. Tenkorang, University of Nebraska at Kearney, USA

Bruce R. Elder, University of Nebraska at Kearney, USA

\begin{abstract}
Literature is full of studies on the relationship between trade and investment. Since trade agreements have the potential of altering this relationship, this study employed gravity model analysis to determine how NAFTA might have affected trade and investment among member countries. Overall improvement in NAFTA economy enhanced exports in the region; however, it was relative improvement in domestic economy that attracted foreign investment. Responsiveness plots show that the impact of NAFTA on exports was short lived, but was longer on FDI.
\end{abstract}

Keywords: NAFTA; exports; FDI; gravity model; responsiveness

\section{INTRODUCTION}

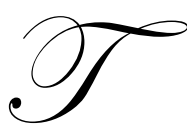

he relationship between trade and foreign direct investment (FDI) is either complementary or substitutable. Because they affect each other in any way, trade and foreign direct investment (FDI) are considered two of the most important methods for entering a foreign market. When trade is unrestricted, it involves less risk than foreign direct investment. Hence, the goal of the World Trade Organization (WTO) is that member countries will have access to each other's market and enjoy relatively low import tariffs. Although WTO members stand to benefit from free trade (job creation, competition, new markets, and investment), it is regional trade agreements that enhance such benefits (Shadlen, 2005). The tenets of the enhanced benefits led to the creation of the North American Free Trade Agreement (NAFTA) in 1994. However, the benefits attributed to NAFTA are often subjects of contention. For instance, opponents of NAFTA quickly attribute any success choked to the value of the U.S. dollar. There are many studies on FDI and trade (as would be seen later), but none has been done specifically for the three only NAFTA economies. The objective of the paper is to analyze the impact of NAFTA on the economies of the three member countries through trade and investment for the periods before and after the introduction NAFTA. The analysis employs gravity modeling and country-pair data.

The North American Free Trade Agreement is an agreement between the U.S., Canada, and Mexico to expand trade and investment between them. It is the largest free trade region in the world and accounts for about $\$ 17$ trillion worth of traded goods and services (USTR.GOV). Soon after the advent of NAFTA, tariffs on many imports were eliminated (Figure 1). As of 2008, the region remains tariff free and seeks to eliminate non-tariff barriers as well (commerce.gov). Also, the three countries have some of the lowest import tariffs in the world. 


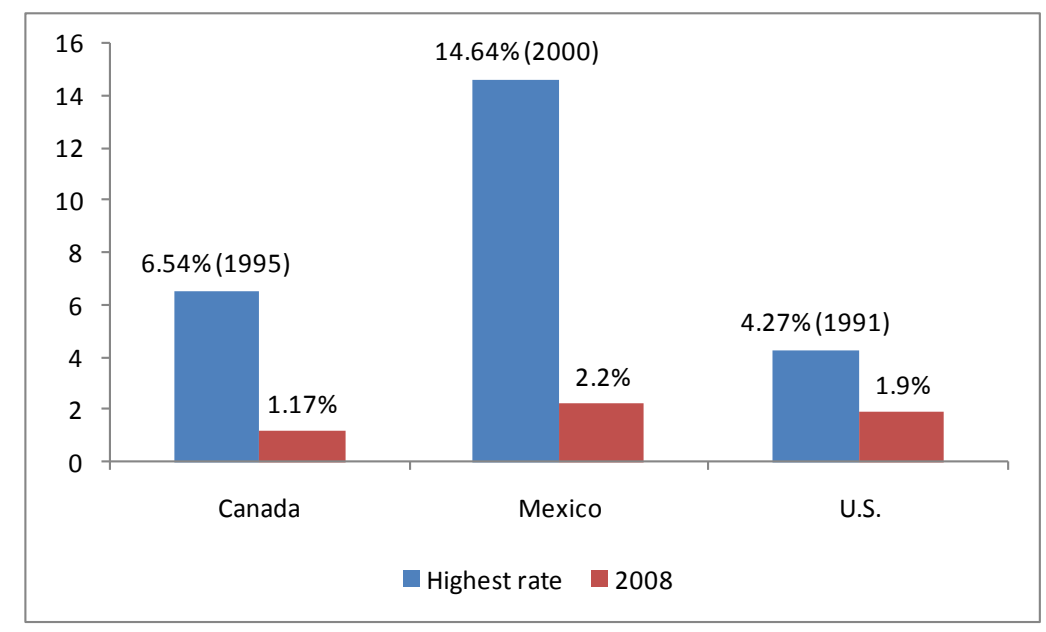

Figure 1: Tariff Rates in the U.S., Canada, and Mexico

Trade records show that member countries have benefited from the agreement. The Office of the United States Trade Representative reports a 198 percent increase in trade among the three countries between 1993 and 2006. US exports to Canada and Mexico increased by 157 percent compared to an increase of 103 percent to the rest of the world. In 2008, although the U.S. had a goods trade deficit ( $\$ 75$ billion) with its two land neighbors, it had a services trade surplus ( $\$ 29.6$ billion) with them (USTR.GOVa). Because of the large trade within the region, Canada and Mexico are among the top three U.S. (world's largest economy) trading partners.

Economic reforms in Mexico have been kept on track by NAFTA. Foreign equity has led to higher productivity (Kessel and Kim, 1995). Foreign direct investment (FDI), which used to focus on high-tech, has expanded to include transport, machinery, and metals (Morales, 1999). The abundance of cheap labor in Mexico is an attraction to U.S. firms. This is responsible for 49 percent of the value-added created by in-bond industries in Mexico (INEGI, 1998). As a result, one of the benefits of NAFTA to Mexico is job creation. In 1993, Mexico-U.S. trade created 29,385 jobs in the U.S., but in 2004, 559,564 jobs were displaced in the U.S. (Scott et al, 2006). It is worth noting that the jobs created in Mexico were mostly in Maquiladora industry (metal and equipment, electronics, textiles, paper, and plastic products) and that the agricultural sector continues to experience job losses (Scott et al, ibid). Gruben (2001) even attributes the observed job creation to the devaluation of the peso, and not NAFTA.

While NAFTA is the largest free trade area, the largest bilateral trading relationship in the world is between Canada and the U.S. (Myles and Cahoon, 2004). The Canada-U.S. free trade agreement began in 1989, five years before NAFTA. About $\$ 1.5$ billion worth of goods and services crossed the world's longest land border $(5,524.6$ miles) in 2008. The U.S. was the destination of $78 \%$ of Canadian exports and the source of $56 \%$ of its imports (MSCI, 2010). About one-third of the exports were energy related while motor vehicles accounted for $13.6 \%$ (MSCI, 2010). Canada enjoyed a significantly high trade surplus with the U.S. in the 1990s, but this high surplus, like the job creation in Mexico, has been attributed to the then low value of the Canadian dollar relative to the U.S. dollar and the strong U.S. economy (Dobbin, 2008). A study by Scott et al (2007) shows that unemployment remained the same 15 years after the initial Canada-U.S. free trade agreement. About 400,000 manufacturing jobs were lost between 1989 and 1993 and regained by 2001. It is currently is on a decline again. The energy sector, on the other hand, has experienced significant job growth.

\section{FACTORS INFLUENCING TRADE AND FDI}

Literature shows many factors have influence on FDI and trade relationship. This section is not intended to be exhaustive, but limited in scope to studies more pertinent to international trade, foreign direct investment and exchange rates published in the past two decades. 
In 1996, Brouthers, Werner, and Wilkinson investigated the relationship between FDI inflow and trade balances by the host country's level of development. They postulated that FDI inflow, especially if it is factor seeking, will have a positive impact on a developing country's trade balance, but a negative impact on that of a developed country. They estimated three models to test their hypothesis. Each model had level of development and FDI as its independent variables, but differed with respect to their dependent variables - trade surplus, change in exports, and change in imports. Their results show a short-term negative relationship between trade surplus and FDI inflow in developed countries if the investment is to seek foreign markets; however, in developing countries there is positive relationship if the investment is efficiency-seeking. The general relationship is, however, weak in both cases.

Wilamoski and Tinkler (1999) used a vector error-correction model to study the effect of U.S. FDI in Mexico on U.S. trade with Mexico. Impulse response functions and variance decomposition showed that FDI has a positive impact on exports to and imports from Mexico. In 1999, Hejazi and Safarian conducted a similar study between Canada and 35 other countries and another study in 2001 between U.S. and 51 countries using a gravity model. In both studies, they found that FDI has a stronger impact on exports than on imports, which implies a positive impact on trade balance. For China, Liu et al (2001) examined causal links between FDI and trade for the 1984-1998 period. They found that imports have positive impact on inward FDI and inward FDI has a positive impact on exports.

A qualitative analysis of structural changes induced by FDI inflows in Ireland revealed that uncertainty over macroeconomic and exchange-rate stability, future trading arrangements among others, caused FDI into the Irish manufacturing sector to focus on the home market or geographically proximate markets (Barry and Bradley, 1997). It was also found that export-oriented FDI is better than tariff-jumping FDI for small economies, such as Ireland. As a result, trade liberalization should be a prerequisite for substantial FDI inflows to such small economies.

In 2002, Chung and Alcacer investigated how location characteristics influence FDI in the U.S. manufacturing sector. They examined 1,784 FDI transactions between U.S. and the Organisation for Economic Cooperation and Development (OECD) nations from 1983 to 1993 by estimating a random parameter logistic regression (RPL). Results show that greater market size, lower factor costs, and better access to surrounding states attract FDI inflow. They also found that firms in research-intensive industries are attracted to states with high R\&D. However, overall, R\&D intensity does not attract FDI.

Büthe and Milner (2008) conducted statistical analyses of 122 developing countries for the period1970 to 2000. They used OLS with country fixed effects to estimate the panel data. The independent variables used include cumulative preferential trade agreements (PTAs), GATT/WTO membership, bilateral investment treaties, market size, political instability, and GDP growth, among others. Results showed that WTO members and participants in PTAs had more FDI inflows than otherwise.

Using panel data, Clougherty and Grajek (2008) studied the impact of the International Organization for Standardization (ISO) diffusion on country-pair economic relations. They estimated FDI and export gravity equations using ordinary least squares (OLS). Their estimation revealed that ISO diffusion has no impact on FDI and trade in developed countries, but has a positive impact on inward FDI and exports in developing country.

\section{METHODOLOGY}

The use of gravity models to study trade-FDI relationship is well documented in literature. From the "potluck assumption" in the 1960s to a set of standards established in the late 1990s, the model has come under rigorous review (Baldwin and Taglioni, 2006). Many variables and methods have been employed. The most common variables are FDI inflow and outflow, exports and imports, exchange rate, and the level of economic development in a given host country. According to Baldwin and Taglioni (2006), the basic gravity model is frosted with biases which are often ignored. The biases are due to omitted variables which cause endogeneity problem (Gold medal error), the use of logs of average bi-lateral trade variables as the dependent variable instead of the use of the average of the logs of the variables (Silver medal error), and spurious correlation due to incorrect deflation of 
trade values (Bronze medal error). They showed that nation dummies and pair dummies (for panel data) could solve the problems.

The current study focuses on how trade agreement, specifically NAFTA, has affected FDI and trade in North America. It considers trade and investment flows from each member country to the other member countries. In this light, the proposed model deviates from the traditional bi-directional model, which requires averaging of trade flows between nations to the use of uni-directional trade. Equation 1 below therefore avoids the "Silver medal error." Hejazi and Safarian used a similar model in their 1999 Canadian study. Also, as recommended by Baldwin and Taglioni (2006), the model includes pair dummies for trade between two given nations to solve for the "Gold medal error" using panel data. Lastly, the included time dummy corrects the bronze medal error.

\section{ESTIMATED MODEL}

Inflow of FDI has a positive impact of exports when it takes advantage of cheap resources in the host country. In this case, the produced goods are exported back to the originating country of the investment. The equation below is based on this assertion:

$$
\mathrm{X}_{\mathrm{i}, \mathrm{j}}=b_{0}+b_{1} \mathrm{FDI}_{\mathrm{i}, \mathrm{j}}+b_{2} \mathrm{GDP}_{\mathrm{i}}+b_{3} \mathrm{GDP}_{\mathrm{j}}+b_{4} \mathrm{ER}_{\mathrm{i}, \mathrm{j}}+b_{5} \mathrm{~N}+b_{6} \mathrm{UC}+b_{7} \mathrm{UM}+b_{8} \mathrm{~T}
$$

Where

$$
\begin{aligned}
& X_{i, j}=\quad \text { Exports value from country } i \text { to country } j \\
& \mathrm{FDI}_{\mathrm{i}, \mathrm{j}}=\quad \text { inward Foreign direct investment stocks from } \mathrm{j} \text { to } \mathrm{i} \\
& \mathrm{GDP}_{\mathrm{i}}=\quad \text { Gross Domestic product of } \mathrm{i} \\
& \mathrm{GDP}_{\mathrm{j}}=\quad \text { Gross Domestic product of } \mathrm{j} \\
& \mathrm{ER}_{\mathrm{i}, \mathrm{j}}=\quad \text { Exchange Rate between } \mathrm{i} \text { and } \mathrm{j} \\
& \mathrm{N}=\quad \text { NAFTA dummy: } 1 \text { for 1995-2002; } 0 \text { for 1990-1994 } \\
& \mathrm{UC}=\quad \text { US-Canada pair dummy: } 1 \text { for US-Canada data, } 0 \text { otherwise } \\
& \mathrm{UM}=\quad \text { US-Mexico pair dummy: } 1 \text { for US-Mexico data, } 0 \text { otherwise } \\
& \mathrm{T}=\text { time variable }
\end{aligned}
$$

The inclusion of the country pair dummies and time variable solve the gold medal and bronze medal errors, respectively, identified by Baldwin and Taglioni (2006). While there is no clear impact of exports on FDI inflow, the existence of unrestricted exports from country $i$ to $j$ could motivate FDI inflow from $j$ to $i$ to take advantage of cheap resources. Hence, estimating an FDI function below, together with the export function above, would seem appropriate. However, it is past exports that are likely to have influence on current FDI inflow, hence, a lagged export (Exlag) is used instead of current exports.

$$
\mathrm{FDI}_{\mathrm{i}, \mathrm{j}}=a_{0}+a_{1} \mathrm{Exlag}_{\mathrm{i}, \mathrm{j}}+a_{2} \mathrm{GDP}_{\mathrm{i}}+a_{3} \mathrm{GDP}_{\mathrm{j}}+a_{4} \mathrm{ER}_{\mathrm{i}, \mathrm{j}}+a_{5} \mathrm{~N}
$$

Exports data were obtained from Foreign Trade Statistics of the US Census Bureau and Statistics Canada, CANSIM. They are in millions of US dollars on a nominal basis. FDI data are from UNCTAD WID country profiles and are in millions of dollars. For exchange rate (ER), annual rate between two countries were used. The source of GDP data is the Statistics Division of the United Nations.

Hausman endogeneity test revealed that OLS estimation is more efficient than a 2SLS estimation. However, each equation was separately estimated with Maximum Likelihood method in order to correct for autocorrelation. Also, the inclusion of GDP and exports data is likely to cause collinearity problems. Condition index for both equations were 19.75 and 5.11, which indicate moderate level of collinearity. 


\section{RESULTS}

Table 1 shows the maximum likelihood estimates of equations 1 and 2. The models are all generally of good fit with statistically significant $F$ values. Adjusted $R^{2}$ are above 0.80 . Correcting for autocorrelation improved Durbin-Watson statistics from 0.94 and 0.89 to 1.62 and 1.91 in that order.

Table 1: Results Of Maximum Likelihood Estimates Of Exports And Fdi Models

\begin{tabular}{|l|l|l|l|l|l|l|l|l|l|l|l|l|}
\hline & Intercept & FDI & GDPd & GDPf & ER & Dnafta & UC & UM & time & DW & $\begin{array}{l}\text { Adj } \\
\mathbf{R}^{2}\end{array}$ & F value \\
\hline Exports & $-14896^{*}$ & 0.0289 & $0.0191^{*}$ & $0.0230^{*}$ & -477.3 & 4668 & -22467 & $-83817^{*}$ & -1353 & 1.62 & 0.96 & $559^{*}$ \\
\hline model & $(0.0122)$ & $(0.8276)$ & $(0.0001)$ & $(0.0001)$ & $(0.425)$ & $(0.1675)$ & $(0.276)$ & $(0.0009)$ & $(0.145)$ & & & $(0.0001)$ \\
\hline & & & & & & & & & & & & \\
\hline & Intercept & $\begin{array}{l}\text { Lagged } \\
\text { Exports }\end{array}$ & GDPd & GDPf & ER & Dnafta & & & & DW & $\begin{array}{l}\text { Adj } \\
\mathbf{R}^{2}\end{array}$ & F value \\
\hline FDI & 19217 & $0.4119^{*}$ & $0.0044^{*}$ & $-0.0056^{*}$ & $-5240^{*}$ & $7702^{*}$ & & & & 1.91 & 0.85 & $193^{*}$ \\
\hline model & $(0.1091)$ & $(0.0001)$ & $(0.0016)$ & $(0.0001)$ & $(0.0001)$ & $(0.039)$ & & & & & & $(0.0001)$ \\
\hline
\end{tabular}

$\mathrm{P}$ values in parenthesis

*Statistically significant at 5 percent level

The results indicate a positive relationship between FDI and exports. While this relationship is statistically insignificant in the export equation, FDI responds significantly to previous years' exports. Both domestic and foreign GDP have a significantly positive impact on exports. In regard to FDI, however, foreign GDP has a negative influence on FDI inflow. This implies that while overall improvement in NAFTA economy enhances exports in the region, it is relative improvement in domestic economy that attracts foreign investment. The exchange rate coefficients are negative, but only significant in the FDI equation. As a result, depreciation of domestic currency attracts FDI inflow. The positive impact of NAFTA was significant on FDI, but not on exports.

\section{RESPONSIVENESS}

The estimated coefficients were used to compute elasticities which were subsequently used to plot the figures below. Focus is placed on plots with conspicuous changes. Figure 1 shows the responsiveness of exports to FDI. While the responsiveness was falling before the advent of NAFA, it flattened after NAFTA.

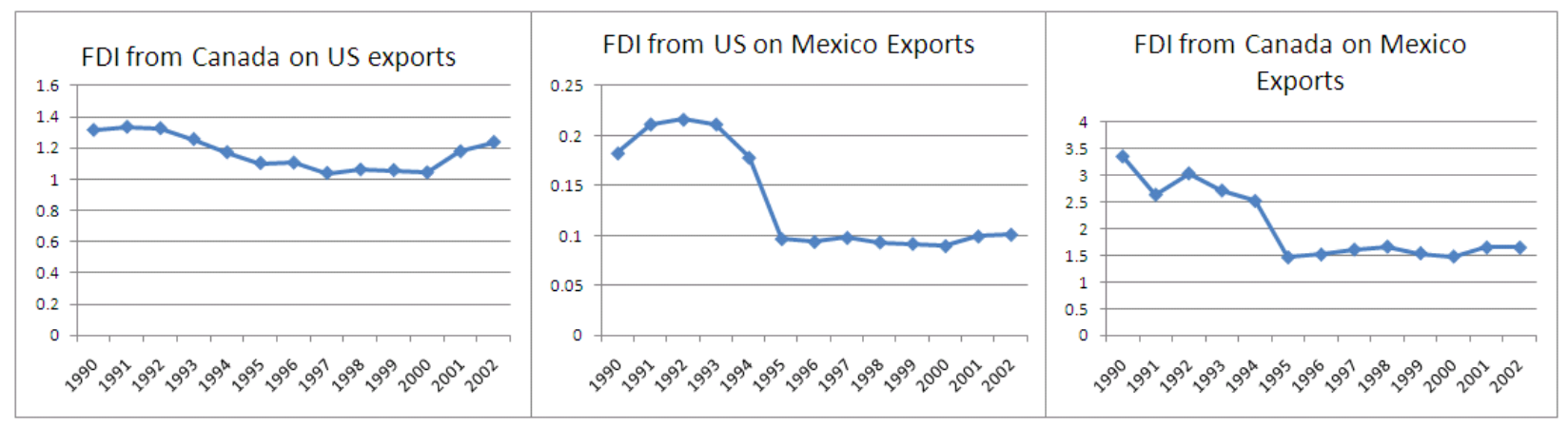

Figure 1: Responsiveness of Exports to FDI Inflow

Figure 2 shows that the responsiveness of exports to exchange rate changes is weakening over time. Although NAFTA caused a noticeable increase in responsiveness, it was short lived. 
Figure 4 shows that while the responsiveness of Mexico and Canada exports to US GDP had a similar pattern to the response of US exports to their respective GDPs, the former was significantly greater than the latter.

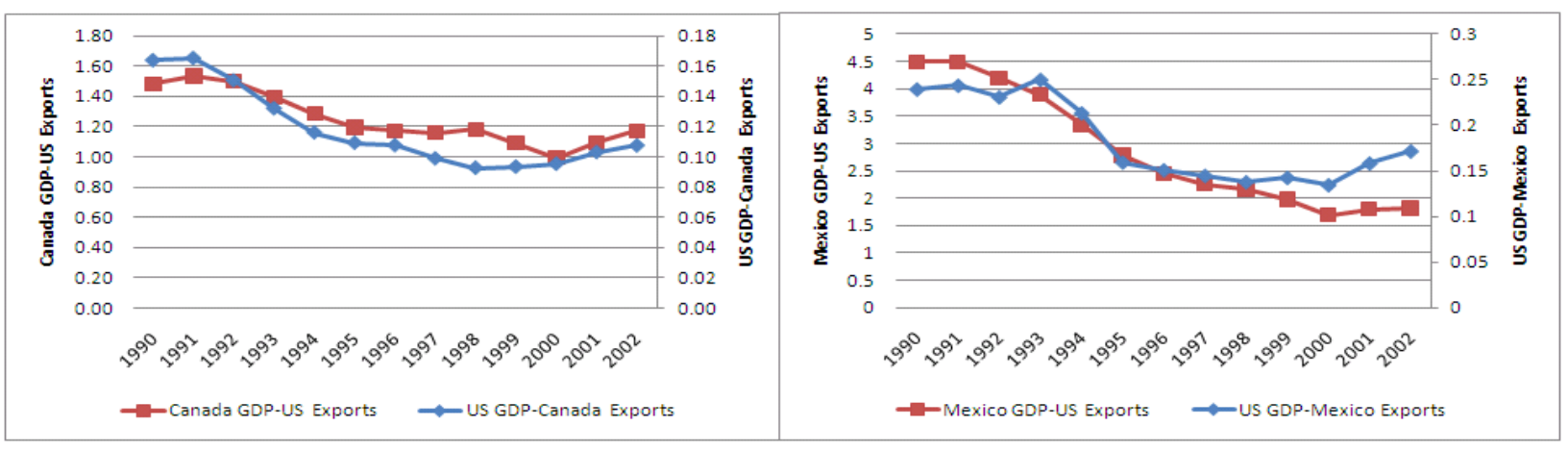

Figure 4: Comparison of Exports-foreign GDP Response between US and Other NAFTA Members

\section{CONCLUSION}

The paper set off to examine the impact NAFTA have had on trade and investment on its member economies. The study employed a gravity model which took into account the three medal errors identified by Baldwin and Taglioni (2006). Although the study did not find evidence of complementary impact of investment on trade, a plot of the responsiveness of trade to investment shows that responsiveness fell sharply and stabilized after NAFTA. There is strong evidence of previous trade inducing inflow of foreign investment. Also, NAFTA destabilized the relation between exchange rate and trade for just one year. The study also revealed that positive relationship between economic performance and trade weakens as the member economies improve, and vice versa.

\section{AUTHOR INFORMATION}

Dr. Beverly J. Frickel has been on the faculty of the Dept. of Accounting and Finance at the University of Nebraska at Kearney since 2001. She received her Ph.D. from the University of Nebraska at Lincoln. She served on the faculty of the University of Central Oklahoma and University of North Texas prior to her years at UNK.

Vani V. Kotcherlakota received her Ph.D. from Andhra University, Waltair, A.P. India in Industrial Economics. She holds two Master of Arts degrees from Waltair and Queen's University, Kingston, Canada. Vani has taught in several universities in India, Finland, Canada, and the United States. Since 1986, Dr. Kotcherlakota has been with the University of Nebraska at Kearney teaching in the Economics Department.

Frank Tenkorang had his B.S. degree from University of Ghana, in 1996 after which he worked as a research assistant at the same university. He obtained his M.S. and Ph.D. degrees from University of Wyoming and Purdue University, respectively in 2002 and 2006. Frank is currently an assistant professor at University of Nebraska, Kearney. He does research in agricultural economics, including econometric analysis.

Bruce Elder holds a B.S. degree from the University of Nebraska at Kearney (1977) and a J.D. from the University of Nebraska College of Law (1980). He was formerly in private practice as an attorney and currently he is a professor of business at the University of Nebraska at Kearney where he teaches graduate and undergraduate courses in business law. His ongoing research interests include business ethics, employment law, and water law. 


\section{REFERENCES}

1. Baldwin, R. and Taglioni, D. (2006). Gravity for Dummies and Dummies for Gravity Equations. National Bureau of Economic Research (NBER) working paper series, No. 12516 http://www.nber.org/papers/w12516

2. Barry, F. and Bradley, J. (1997). FDI and Trade: The Irish Host-Country Experience. The Economic Journal Vol.107 (November), pp. 1798-1811.

3. Brouthers, L. E., Werner, S., and Wilkinson, T. J. (1996). The Aggregate Impact of Firms' FDI Strategies on the Trade Balances of Host Countries. Journal of International Business Studies, Vol. 27, No. 2 (2nd Qtr.), pp. 359-373

4. Büthe, T. and Milner, H. V. (2008). The Politics of Foreign Direct Investment into Developing Countries: Increasing FDI through International Trade Agreements? American Journal of Political Science, Vol. 52, No. 4, pp. 741-762

5. Chung, W. and Alcácer, J. (2002). Knowledge Seeking and Location Choice of Foreign Direct Investment in the United States Author(s): Source: Management Science, Vol. 48, No. 12 (Dec.), pp. 1534-1554

6. Clougherty, J.A. and Grajek, M. (2008). The impact of ISO 9000 diffusion on trade and FDI: A new institutional analysis. Journal of International Business Studies Vol. 39, pp. 613-633

7. Commerce.gov (2008). Top U.S. Export Markets. Free Trade Agreement and Country Facts Sheets. U.S. Department of Commerce, International Trade Administration. Summer.

8. Dobbin, M. (2008). Debunking the free trade myth: NAFTA is by far the worst agreement Canada ever signed. CCPA Monitor, Canadian Centre for Policy Alternatives. Retrieved 09 Jun, 2010. http://findarticles.com/p/articles/mi_7497/is_200804/ai_n32270937/

9. Gruben, C. (2001). Was NAFTA behind Mexico's high maquiladora growth? Economic \& Financial Review. Third quarter. pp. 11-21.

10. Hejazi, W. and Safarian, A.E. (1999). Modelling Links Between Canadian Trade and Foreign Direct Investment. Perspective on North American Free Trade, Industry Canada Research Publications, Paper No. 2.

11. Hejazi, W. and Safarian A.E. (2001). The Complementarity Between U.S. Foreign Direct Investment Stock and Trade. Atlantic Economic Journal. Dec, 2001.

12. INIGI (1998). Industria maquiladora de exportaci6n, Aguascalientes: August, p 14

13. Kessel, G. and Kim, C-S. (1995). Caracternsticas del desarrollo technol6gico y su contribuci6n crecimiento de la producci6n industrial y al crecimiento econ6mico: el caso de Mexico', in Pablo

14. Liu, X., Wang, C., and Wei, Y. (2001). Causal links between foreign direct investment and trade in China. China Economic Review, Vol. 12, No. 2/3, pp. 190-202.

15. Morales, I. (1999). NAFTA: The Institutionalisation of Economic Openness and the Configuration of Mexican Geo- Economic Spaces. Third World Quarterly: Vol. 20, No. 5, New Regionalisms in the New Millenium (October), pp. 971-993

13. MSCI (2010). NAFTA and Markets: US Economic Impacts on Canadian Equities. Research Bulletin, January 2010.

14. Mulds del Pozo, (ed), Aspectos tecnoldgicos de la modernizacidn industrial de Mexico, Mexico: FCE, 1995, pp 124-143.

15. Myles, C. G. and Cahoon, M. (2004). Canada and NAFTA: a 10-year measure of success in Canadian-U.S. agricultural trade - North American Free Trade Agreement. AgExporter, Vol. 16. No. 1., USDA/FAS.

16. Shadlen, K. C. (2005). Exchanging Development for Market Access? Deep Integration and Industrial Policy under Multilateral and Regional-Bilateral Trade Agreements. Review of International Political Economy, Vol. 12, No. 5 (Dec.), pp. 750-775

17. Scott, R., Salas, C., Campbell, B., and Faux, F. (2006). Revisiting NAFTA Still not working for North America's workers. EPI Briefing Paper, No. 173.

18. Wilamoski, R. and S. Tinkler (1999). The Trade Balance Effects of U.S. Foreign Direct Investment in Mexico. Atlantic Economic Journal, Vol. 27, No. 1, p 24-37.

19. USTR.GOV. North American Free Trade Agreement (NAFTA). Office of the United States Trade Representative, Executive Office of the President. Retrieved June 8, 2010. http://www.ustr.gov/tradeagreements/free-trade-agreements/north-american-free-trade-agreement-nafta. 